information on the status of ecosystems by creating an online open-access toolbox for housing and analysing scientific data, developing a portfolio of scientific and popular publications, improving public knowledge, and integrating the Red List of Ecosystems with the IUCN Red List of Threatened Species and World Database of Protected Areas to enhance biodiversity conservation planning. The biodiversity policy aim is to use the Red List of Ecosystems to engage actively with governments in the region in the development of national Red Lists of Ecosystems, informing regional economic, social and environmental cooperation organizations, and maintaining a high profile at key global biodiversity-related scientific meetings.

By using the experience of the IUCN Red List of Threatened Species as a model, the present effort has the potential to influence allocation of conservation resources to threatened ecosystems throughout the world, and to influence the policy process of biodiversity-related international conventions such as the Convention on Biological Diversity (e.g. Aichi Biodiversity Target 5 adopted in Nagoya in October 2010) and the Ramsar Convention on Wetlands of International Importance. Similar effects could also be expected at the national level, as public knowledge of ecosystem risk increases and countries around the world implement Red Lists of Ecosystems. An IUCN Red List of Ecosystems also has the potential to serve as an important instrument to guide investments for several Millennium Development Goals, as poverty reduction and improvements in health are dependent on properly-functioning ecosystems that provide important goods and services for human well being. For more information, updates and information on how to become involved please visit http:// www.iucn.org/about/union/commissions/cem/cem_work/ tg_red_list/

Jon Paul Rodríguez ${ }^{*}$ and Kathryn M. Rodríguez-Clark Centro de Ecología, Instituto Venezolano de Investigaciones Científicas, Apdo. 20632, Caracas 1020-A, Venezuela

E-mail jonpaul@ivic.gob.ve

DAVID A. KEITH Australian Wetlands and Rivers Centre, University of New South Wales, Sydney, Australia, and New South Wales Office of Environment \& Heritage, Hurstville, New South Wales, Australia

EDMUND G. BARROW IUCN Ecosystem Management Programme, Gland, Switzerland

PAtRICK Comer NatureServe, Boulder, Colorado USA

María A. Oliveira-Miranda Provita, Caracas, Venezuela

${ }^{*}$ Also at Provita, Caracas, Venezuela, and IUCN Commission on Ecosystem Management and IUCN Species Survival Commission, Gland, Switzerland

\section{Mangrove conservation amidst land sharks}

Mangroves in and around Mumbai, India, have undergone massive destruction and c. $70 \%$ of Mumbai's mangroves have been destroyed by various development activities. In spite of the protection afforded by several Acts, mangroves in the city continue to face destruction. Since 2005 the Conservation Action Trust, a registered non-profit organization formed to protect the environment, and particularly wildlife and forests, with a focus on mangroves, has been handling a number of cases that were filed by the Bombay Environmental Action Group prior to the formation of the Trust. The Trust is dedicated to providing assistance in the form of technical information, legal advice, aid and equipment to those who are confronting environmental problems. It works closely with Forest Departments and NGOs working to protect nature and natural resources.

To protect the remaining mangroves in and around Mumbai, Debi Goenka, the Executive Trustee of the Conservation Action Trust, filed a Writ Petition in the Bombay High Court seeking the Court's intervention to inhibit the destruction of mangroves. The result was an order passed by the Honourable High Court on 6 October 2005 that states: (1) There shall be a total freeze on the destruction and cutting of mangroves. (2) All construction and rubble/garbage dumping on the mangrove areas shall be stopped forthwith. (3) Regardless of ownership of the land, all construction taking place within $50 \mathrm{~m}$ on all sides of all mangroves shall be forthwith stopped. (4) All Government owned land will be notified as Protected Forests and handed over to the Forest Department.

However, there was a delay in notifying the areas as Protected Forests, in view of which a further order dated 27 January 2010 was passed to protect the mangroves in Raigad, Ratnagiri and Sindhudurg Districts. As per this Order, 'no non forests activity should be permitted by the respondent state in these mangrove areas throughout the state of Maharashtra which shall be subject to section 2 of the Forests (Conservation) Act 1980 and Environment Protection Act and Rules, without taking permission from the competent authority'.

Based on these orders and the efforts of the Conservation Action Trust for protection and conservation of mangroves, in November 2011 the Supreme Court rejected a plea by a local builder to convert the mangroves to salt pans (at Dahisar, Mumbai). The builder had already constructed new bunds and dumped thousands of truck loads of debris so as to take over a 430 -acre mangrove-covered site for private development. In the field the Trust's team was repeatedly threatened, attacked at least twice and had equipment stolen. However, the Trust continued the campaign along with a local residents' group and was able to halt the destruction of these mangroves. 
The same builder, after flouting the orders of the Supreme Court in the matter of removal of debris and restoration of the original bund, filed a petition challenging the action of the Collector (an Officer of the Indian Administrative Service) who had seized his bank accounts and recovered INR 1.25 crores as dues to be paid to the contractor who had removed the debris. The High Court rejected the builder's pleas and passed strictures against him.

The filing of the case for the protection of mangroves has led to $>5,800$ ha of mangrove areas in Mumbai, Navi Mumbai and Thane being notified as Protected Forests. These areas have been handed over to the Forest Department. The efforts and advocacy of the Conservation Action Trust have led to a special Mangroves Cell being created within the Forest Department. This Cell is headed by an officer of Chief Conservator of Forests rank.

ShweTA BHATT Conservation Action Trust, Mumbai, India E-mailshweta@cat.org.in

\section{China's role in trade in ivory and elephant parts from Lao PDR}

Historically known as the Land of a Million Elephants, the wild Asian elephants Elephas maximus of the Lao People's Democratic Republic remain widely but patchily distributed throughout the country. There is limited information on the trade in ivory or elephant parts in the country but, strategically situated between the world's largest ivory traders, Thailand and China, the trade may be substantial. Economic ties with Thailand have traditionally been strong but in recent years Chinese economic investments in Lao have boomed and, after Thailand, China is now Lao's second largest trading partner. China, Thailand and Lao are all signatories to CITES and no international trade in elephants, their parts or their ivory is permitted. Within Thailand domestic trade in ivory obtained from domestic elephants is permitted and, under tight controls, domestic trade in labelled and registered African ivory is allowed in China. In neither country is trade in elephant parts other than ivory permitted. In Lao elephants are protected and trade in elephants, their parts or ivory is illegal; however, in general, wildlife laws are poorly enforced. Thailand's wild elephant population numbers in the thousands, and that of Lao possibly up to a thousand, but in China only a few hundred wild elephants remain. Taken together this may suggest an emerging role for Lao in the trade in ivory and elephant parts, both domestically and cross-border to China.

We have conducted a series of surveys of wildlife trade in Lao's capital Vientiane, just across the border with Thailand, most recently in August 2011. In the late 1990s to early 2000 s most ivory or elephant parts were traded in the Morning
Market (Telaat Sao) and a series of stalls opposite the nearby central post office. Here, during a 1-day survey in May 1999, Nooren \& Claridge (End of the Game, 2001, IUCN Amsterdam) observed 57 molar pieces, three pieces of skin, one tail, and an unquantified amount of elephant bone for sale. No ivory was recorded. In November 2002 one of us (CRS) observed 101 pieces of carved ivory and four raw tusks or tusk tips, and a few small pieces of elephant skin. Most observations were made at the Morning Market but also at one luxury hotel, and the main clientèle appeared to be either local Laotians or visitors from Thailand (the latter apparently only interested in ivory, not other elephant parts). In August 2011 we observed 12 molar pieces and 15 pieces of elephant skin offered for sale in 22 separate shops or stalls. A total of 2,379 pieces of carved ivory and 12 raw tusks or tusk tips were observed, openly displayed for sale. The trade in elephant parts, used largely for traditional medicine, was still concentrated in the Morning Market. The vendors were all Laotian and prices were in LAK; Laotians and Chinese were the main buyers. The trade in ivory had clearly shifted to antique shops, souvenir shops, jewellery and gem parlours and the lobbies of luxury hotels. The largest quantities of ivory, and the heaviest carved pieces, were displayed in two major luxury hotels, targeting high-end customers.

The main ivory traders and the main clientèle were Chinese (either Chinese nationals or Laotians of Chinese decent). Figurines with Maitreya and Kwan Yin as subjects (representing generosity, compassion and mercy in a Chinese cultural context) suggest that vendors were targeting Chinese customers. Name seals (hanko) observed for sale are exclusively produced for East Asian markets, further suggesting a northwards flow of ivory. Price tags showed prices in CNY or USD (not in LAK), placards were written in Chinese characters, and conversations between vendors and buyers took place in Chinese. Apart from one vendor hiding a large tusk upon our arrival in the shop, all trade in ivory and elephant parts was open, and vendors were generally keen to show their merchandise and discuss details. We were informed by several vendors that the ivory for sale originated from Laotian elephants (with some of the more intricate carving done in Vietnam or China) but we had no way of verifying this.

To the best of our knowledge no regular monitoring of the ivory trade is conducted by the country's law enforcement agencies, and Lao has never reported any seizures of ivory to the Elephant Trade Information System of CITES. The openness of the trade and the willingness of the vendors to talk about the trade attests to insufficient enforcement efforts. It is clear from our surveys that regular monitoring of the markets in Vientiane, including luxury hotels, is needed. Offenders should be prosecuted to the full extent of the law, reflecting the seriousness of the crime and to serve as a strong deterrent. International cooperation in 